\title{
THE CYTOPLASMIC ACCUMULATION OF NON-POLYADENYLATED RNA IN RAT THYMOCYTES IS DIFFERENTIALLY CHANGED AT AN EARLY TIME OF PROTEIN SYNTHESIS INHIBITION
}

\author{
by \\ MOGENS ENGELHARDT \\ Institute of Experimental Hormone Research \\ University of Copenhagen, Nørre Alle 71, DK-2100 Copenhagen $\varnothing$
}

Keywords: Protein synthesis inhibitor, polyadenylated RNA, non-polyadenylated RNA, cycloheximide, emetin, puromycin, pactamycin, thymocyte, histone mRNA

\begin{abstract}
The cytoplasmic accumulation of newly synthesized RNA in rat thymocytes has been analyzed during the first $45 \mathrm{~min}$ of protein synthesis inhibition by cycloheximide, emetin, puromycin or pactamycin. Electrophoretic fractionation of double labelled RNA showed no changes in the isotope ratio of single fractions of poly(A)'-RNA within an experimental error corresponding to \pm 2 to \pm 20 molecules per cell. In poly(A)-RNA, two types of changes were induced. All four inhibitors stimulated the incorporation in presumptive histone mRNA and inhibited the accumulation of $18 \mathrm{~S}$ rRNA. A stimulated accumulation of tRNA was induced only by cycloheximide and emetin, two polysome stabilizing compounds. Labelling of $28 \mathrm{~S} \mathrm{rRNA}$ was only slightly affected, except in the presence of cycloheximide, where it increased more than twofold. This suggests that cycloheximide may induce an accelerated nuclear-cytoplasmic transfer of $28 \mathrm{~S}$ rRNA. The changes induced in poly(A)-RNA are thus either inhibitor specific, or a result of a sensitivity to protein synthesis per se.
\end{abstract}

\section{INTRODUCTION}

Eucaryotic cells respond to environmental changes, that affect cellular growth, by a coordinate response of a number of biochemical reactions, including the metabolism of RNA and protein. A more detailed insight into the relation between RNA and protein synthesis is obtained by treatment with protein synthesis inhibitors, which have been shown to induce a rapid, or stringent, change in the synthesis rate of several RNA species.

The stringency of such responses is generally explained by the existence of hypothetical gene regulatory intermediates, possibly proteins, which are either very shortlived, or, exerting their function with a very short delay after being synthesized, so that their effective concentration may be changed very soon after protein synthesis inhibition. The rapid inhibition of rRNA synthesis observed by treatment with protein synthesis inhibitors might thus be due to a depletion of newly synthesized ribosomal proteins, that are normally present in minute amounts (17, 25). However, it leaves open the question as

\footnotetext{
Abbreviations: EDTA $=$ ethylenediamine tetraacetic acid; Hepes $=\mathrm{N}$-hydroxyethylpiperazine-2-ethane sulphonic acid; $\mathrm{mRNA}=$ messenger ribonucleic acid; poly $(\mathrm{A})$ = poly(adenylic acid); poly $(\mathrm{U})$ = poly(uridylic acid); rRNA = ribosomal ribonucleic acid; SDS = sodium dodecyl sulphate; tRNA = transfer ribonucleic acid; TES = $\mathrm{N}$-tris(hydroxymethyl)methyl-2-aminomethane sulphonic acid; Tris = tris(hydroxymethyl)aminomethane.
} 
to whether the inhibition of rRNA synthesis might also be caused by shortage of positive gene regulatory proteins.

A stimulation of tRNA synthesis has been reported as an early response to protein synthesis inhibition in liver cells (22) and chick fibroblasts (24), and suggested the existence of negative gene regulatory intermediates, either in the form of proteins, or specific tRNAs.

In studies of adenovirus infection, protein synthesis inhibition was found to stimulate viral transcription, provided early gene expression had been allowed to take place before treatment (6). This indicated, that gene activating proteins might be encoded by an early viral gene region, and suggested that viral gene expression in other regions is balanced by activators and repressors with a short half-life.

Indirect evidence for similar mechanisms of sequential gene activation has come from investigations of steroid hormone action, since in several cases, steroid induction of specific mRNA is completely blocked by protein synthesis inhibitors, only when added during the initial period of hormone action $(4,7,12,16)$.

In the course of a study of RNA synthesis in rat thymocytes during early cortisol action, we wished to know to which extent the cellular RNA production was actually perturbed during a short treatment with protein synthesis inhibitors. It appeared, that although the effects of protein synthesis inhibition on separate classes of RNA have been widely studied, a quantitative comparison of these effects was not possible, since an analysis of total cytoplasmic RNA could not be found in the literature.

The cytoplasmic accumulation of newly synthesized RNA has been analyzed in the present study by double isotope labelling during the first $45 \mathrm{~min}$ of protein synthesis inhibition. This time interval is short compared to the half-life of most cytoplasmic RNA, and not much longer than the delay between synthesis and cytoplasmic appearance of many RNA species.

\section{MATERIALS AND METHODS}

\subsection{Materials}

Cycloheximide, puromycin, bovine serum albumin (fraction V) and TES were obtained from
Sigma, USA and emetin dihydrochloride from Boehringer Mannhein GmbH, W. Germany. Pactamycin was a gift from Dr. J.E. GRADY, the Upjohn Company, USA. Dextran sulphate 500 and poly(U)Sepharose were products of Pharmacia Fine Chemicals, Sweden. Streptomycin (Novoject) was obtained from Novo Industry A/S, Denmark, and medium 199 was from Gibco Bio-Cult Ltd., Scotland. Triisopropylnaphtalene sulphonate ( $90 \%$ pure) was purchased from Eastman Kodak Company, USA, and Hepes was obtained from Calbiochem, USA. Sodium dodecyl sulphate was from BDH Chemicals, Ltd., England and polyethyleneimine cellulose sheets, "Baker-Flex", from J.T. Baker Chemicals, USA. [5- $\left.{ }^{3} \mathrm{H}\right]$-uridine (25-30 $\mathrm{Ci} / \mathrm{mmol}), \quad\left[\mathrm{U}-{ }^{14} \mathrm{C}\right]$-uridine $(482-495 \mathrm{mCi} /$ $\mathrm{mmol})$ and $\mathrm{L}-\left[\mathrm{U}-{ }_{-}^{14} \mathrm{C}\right]$-leucin $(330 \mathrm{mCi} / \mathrm{mmol})$ were products of Amersham International plc, England. If not otherwise stated, all other chemicals were of analytical purity from Merck, W. Germany. Acrylamide and bisacrylamide were purified by recrystallization in acetone (reagent grade) before use.

\subsection{Cell preparation and cultivation}

Rat thymocytes were prepared and cultivated as previously described (9). Briefly, the cells were incubated at $1.5 \times 10^{7} / \mathrm{ml}$ in medium 199 supplemented with $5 \mathrm{mM}$-TES and $5 \mathrm{mM}$-Hepes, 0.1 $\mathrm{mg} / \mathrm{ml}$ streptomycin and $5 \%$ bovine serum albumin. The viability was always higher than $90 \%$ as found by conventional eosin staining.

\subsection{Double isotope analysis of RNA}

Double labelling of RNA was performed in duplicate $5 \mathrm{ml}$ cultures by adding at zero time [U- $\left.{ }^{14} \mathrm{C}\right]$-uridine $(2 \mu \mathrm{Ci} / \mathrm{ml})$ to one culture and $\left[5-{ }^{3} \mathrm{H}\right]$-uridine $(10 \mu \mathrm{Ci} / \mathrm{ml})$ to the other. The uridine concentration in the ${ }^{3} \mathrm{H}$ containing culture was adjusted to that of the ${ }^{14} \mathrm{C}$ containing one by addition of unlabelled uridine $(4 \mu \mathrm{M}$ total concentration). Cycloheximide, puromycin, emetin or pactamycin was added to one of the cultures from a $100 \times$ concentrated stock solution in water or absolute alcohol, the other culture receiving the same volume of solute without inhibitor. $3 \mathrm{~min}$ before the end of the incubation, the cultures were centrifuged 1.5 
min at $37{ }^{\circ} \mathrm{C}(1000 \times \mathrm{g})$ and lysed at $0{ }^{\circ} \mathrm{C}$ in $250 \mu \mathrm{l} 100 \mathrm{~mm}-\mathrm{KCl}, 10 \mathrm{mM}-\mathrm{MgCl}_{2}, 50 \mathrm{~mm}-$ Tris- $\mathrm{HCl}$, pH 7.5 , containing $0.25 \%$ nonidet $\mathrm{NP40}$ and $50 \mu \mathrm{g} / \mathrm{ml}$ dextran sulphate 500 .

The lysates were mixed and centrifuged for $1.5 \mathrm{~min}$ in the cold $(1000 \times \mathrm{g})$. The postnuclear supernatant was extracted at $4{ }^{\circ} \mathrm{C}$ in a total volume of $3 \mathrm{ml} 0.1 \mathrm{M}-\mathrm{Tris}-\mathrm{HCl}$, pH 9.0, containing $0.5 \%$ SDS and $1 \%$ triisopropylnaphtalene sulphonate with an equal volume of redistilled phenol containing $0.1 \%$ hydroxyquinoline, and saturated with $0.1 \mathrm{M}-\mathrm{Tris}-\mathrm{HCl}, \mathrm{pH}$ 9.0. The interphase was reextracted once with $1 \mathrm{ml} \mathrm{0.1} \mathrm{M-Tris-} \mathrm{HCl}, \mathrm{pH} \mathrm{9.0,} \mathrm{and} \mathrm{the} \mathrm{combined}$ aqueous phases extracted two times with phenol until no interphase was visible. The aqueous solution was made $0.6 \mathrm{M}$ in $\mathrm{NH}_{4}$ acetate, and the RNA allowed to precipitate overnight at -20 ${ }^{\circ} \mathrm{C}$ after addition of 2 volumes of absolute alcohol. It was then recollected by centrifugation, washed with $67 \%$ ethanol in $0.24 \mathrm{M}-\mathrm{NH}_{4}$ acetate and partially dried under vacuum. The amount of RNA was determined by UV absorption in $20 \mathrm{mM}$-Tris- $\mathrm{HCl}$, pH 7.5, using $\mathrm{A}_{260 \mathrm{~mm}}^{1 \mathrm{~cm}}$ $(0.1 \%)=21$. Normally $75-100 \mu \mathrm{g}$ RNA was recovered.

The RNA concentration was adjusted to 1 $\mathrm{mg} / \mathrm{ml}$, and $\mathrm{NaCl}$ added to $0.7 \mathrm{M}$. It was then heated to $65^{\circ} \mathrm{C}$ for $1 \mathrm{~min}$, and subjected to affinity chromatography on a column containing approximately $100 \mathrm{mg}$ poly(U)Sepharose, which had been equilibrated with $0.7 \mathrm{M}-\mathrm{NaCl}$, 2 mM-EDTA, 20 mM-Tris- $\mathrm{HCl}, \mathrm{pH}$ 7.5. Poly(A)-RNA was washed out with $900 \mu l$ of the same buffer. Poly(A) ${ }^{+}$-RNA was eluted with $900 \mu \mathrm{l}$ of $80 \%$ deionized formamide in the same buffer without $\mathrm{NaCl}$, and added $30 \mu \mathrm{g}$ unlabelled RNA as a carrier. The RNA was precipitated and recollected as described above, and analyzed by electrophoresis on cylindrical $8 \mathrm{~cm}$ $2.5 \%$ polyacrylamide gels, as described by LOENING (15), using diethylpyrocarbonate (1 $\mathrm{ml} / \mathrm{l}$ ) instead of SDS in the electrophoresis buffer. After scanning at $260 \mathrm{~nm}$, the gels were sliced and counted as previously described (9).

All glassware was autoclaved, and plasticware was treated overnight with an aqueous solution of diethylpyrocarbonate $(1 \mathrm{ml} / \mathrm{l})$ before use. Buffers were made up in sterile water and stored at $-20{ }^{\circ} \mathrm{C}$.

\subsection{Other procedures}

Determination of the isotope ratio of uridine in the culture media was made by mixing equal amounts of medium after removal of the cells at the end of the labelling period. Bovine serum albumine was precipitated with $10 \%$ TCA, and after centrifugation the TCA was removed from the supernatant by extraction with diethylether. Separation of uridine was performed by one dimensional chromatography on polyethyleneimine cellulose sheets, using n-butanol:methanol: $\mathrm{NH}_{4} \mathrm{OH}: \mathrm{H}_{2} \mathrm{O}(60: 20: 20: 1 \mathrm{v} / \mathrm{v})$ followed by counting of the material eluted from the spots with $0.3 \mathrm{M}-\mathrm{NaOH}$.

Analysis of protein synthesis was made by incubating the cells in medium 199 diluted to 1/20 in Hank's balanced salt solution, in order to decrease the concentration of leucin. After the addition of inhibitors, $300 \mu \mathrm{l}$ aliquots were transferred at 0,25 and $50 \mathrm{~min}$ to test tubes containing $15 \mu \mathrm{L}-\left[\mathrm{U}-{ }^{14} \mathrm{C}\right]$-leucin and the incorporation allowed to proceed for $15 \mathrm{~min}$, followed by analysis of the incorporation in TCA precipitable material.

\subsection{Statistical analysis of isotope ratios}

Deviations of the isotope ratio in single gel slices from the integrated mean ratio were measured in terms of standard deviations, denoted by $\mathrm{SD}$, using a statistical test of significance, as previously described (9). For a series of isotope ratios, one-third would be expected to deviate $1 \mathrm{SD}$ or more from the mean. Since sources other than the counting error contributed to the statitical variation of the isotope ratios, and became of major importance when the calculated standard deviations were below $2 \%$, the ratios were considered as being determined with a precision of $\pm 2 \mathrm{SD}$.

\section{RESULTS}

\subsection{Characterization of newly synthesized RNA}

When cytoplasmic RNA was isolated from cells labelled for $45 \mathrm{~min}$ with $\left[{ }^{14} \mathrm{C}\right]$-uridine, fractionated on poly(U)Sepharose and analyzed by polyacrylamide gel electrophoresis, approxi- 


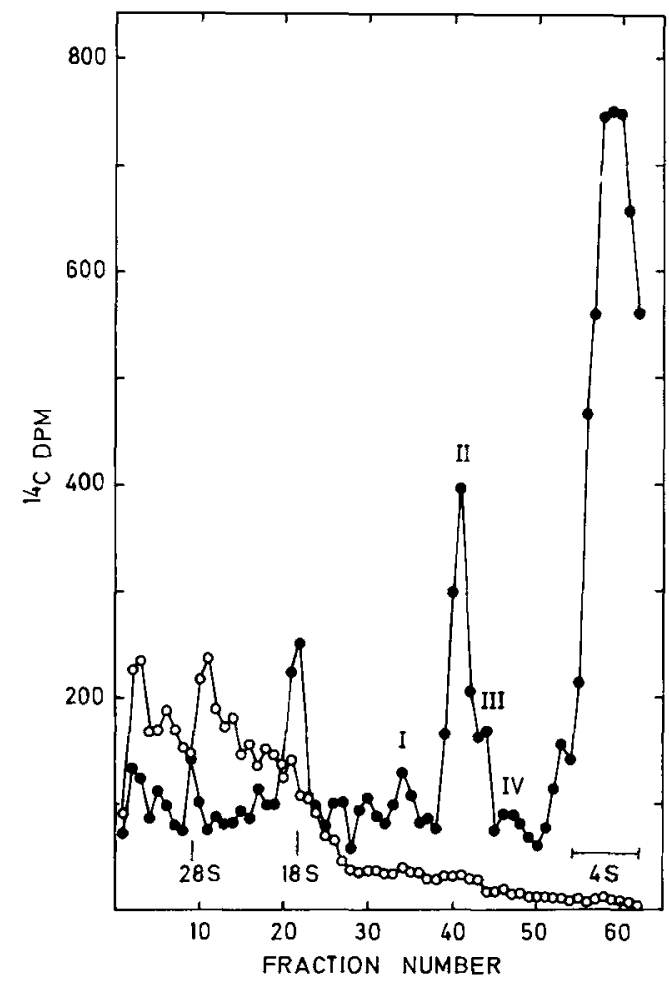

Figure 1. Polyacrylamide gel electrophoresis of cytoplasmic RNA. Thymocytes were labelled for $45 \mathrm{~min}$ with $\left[{ }^{14} \mathrm{C}\right]$-uridine, and the RNA was fractionated on poly(U)Sepharose. Peak I-IV were considered as being mRNAs for histones (see 3.1). O Poly(A) -RNA; Poly(A)-RNA.

mately $40 \%$ of the radioactivity was found in polyadenylated RNA. As shown in Figure 1, the radioactivity in this fraction of presumptive mRNA was present mainly in the high molecular weight region of the gels, whereas the non-polyadenylated RNA was distributed throughout the gels in a highly reproducible pattern, with several distinct peaks of radioactivity. The peaks in fraction 9-10 and 21-22 in Figure 1 were identified as ribosomal RNA since they comigrated with $28 \mathrm{~S}$ rRNA and 18 $S$ rRNA, respectively, and disappeared if actinomycin $\mathrm{D}(0.05 \mu \mathrm{g} / \mathrm{ml})$ was added $30 \mathrm{~min}$ before the start of the labelling period. Moreover, at prolonged labelling, radioactivity accumulated in these peaks, and accounted for more than $80 \%$ of the total incorporation after 2 hours (results not shown). The radioactivity in fraction
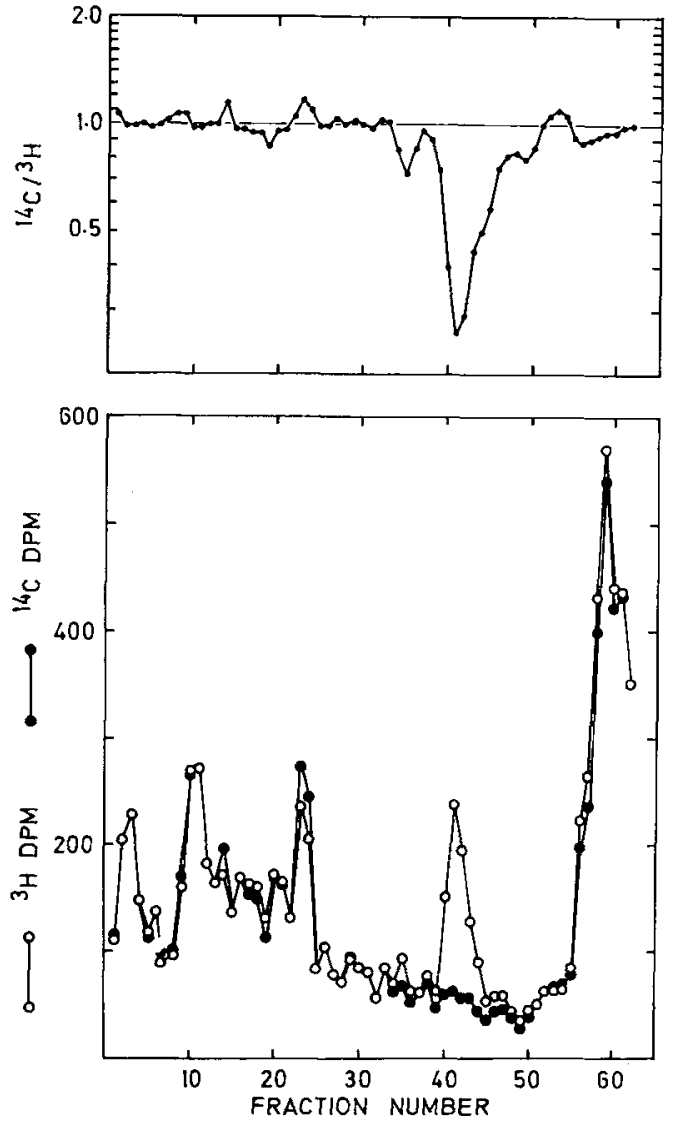

Figure 2. Polyacrylamide gel electrophoresis of double labelled cytoplasmic RNA. Duplicate cultures were labelled for $45 \mathrm{~min}$ in the presence of $\left[{ }^{3} \mathrm{H}\right]$-uridine or $\left[{ }^{14} \mathrm{C}\right]$-uridine. One culture received $5 \mathrm{mM}$-hydroxyurea $10 \mathrm{~min}$ before labelling was initiated. The isotope ratios shown in the upper panel are given as the ${ }^{14} \mathrm{C} /{ }^{3} \mathrm{H}$ ratio for each gel slice, divided by the theoretical ratio. - hydroxyurea $\left({ }^{14} \mathrm{C}\right) ; \mathrm{O}$ control $\left({ }^{3} \mathrm{H}\right)$.

55-62 in Figure 1 comigrated with tRNA, and could be recovered in a $100,000 \times g$ supernatant after pelleting of the polysomes (9). This peak was therefore considered as being tRNA. Finally, the peaks of radioactivity denoted by I-IV in Figure 1 were tentatively identified as being mRNAs for histones, since they were not labelled when DNA synthesis was inhibited with hydroxyurea. This was clearly seen in double labelling experiments even without fractionation on poly(U)Sepharose, as shown in Figure 2. Their apparant molecular weights of $3.0 \times 10^{5}$ (I), $1.9 \times 10^{5}$ (II), $1.5 \times 10^{5}$ (III) and $1.2 \times 10^{5}$ (IV) 


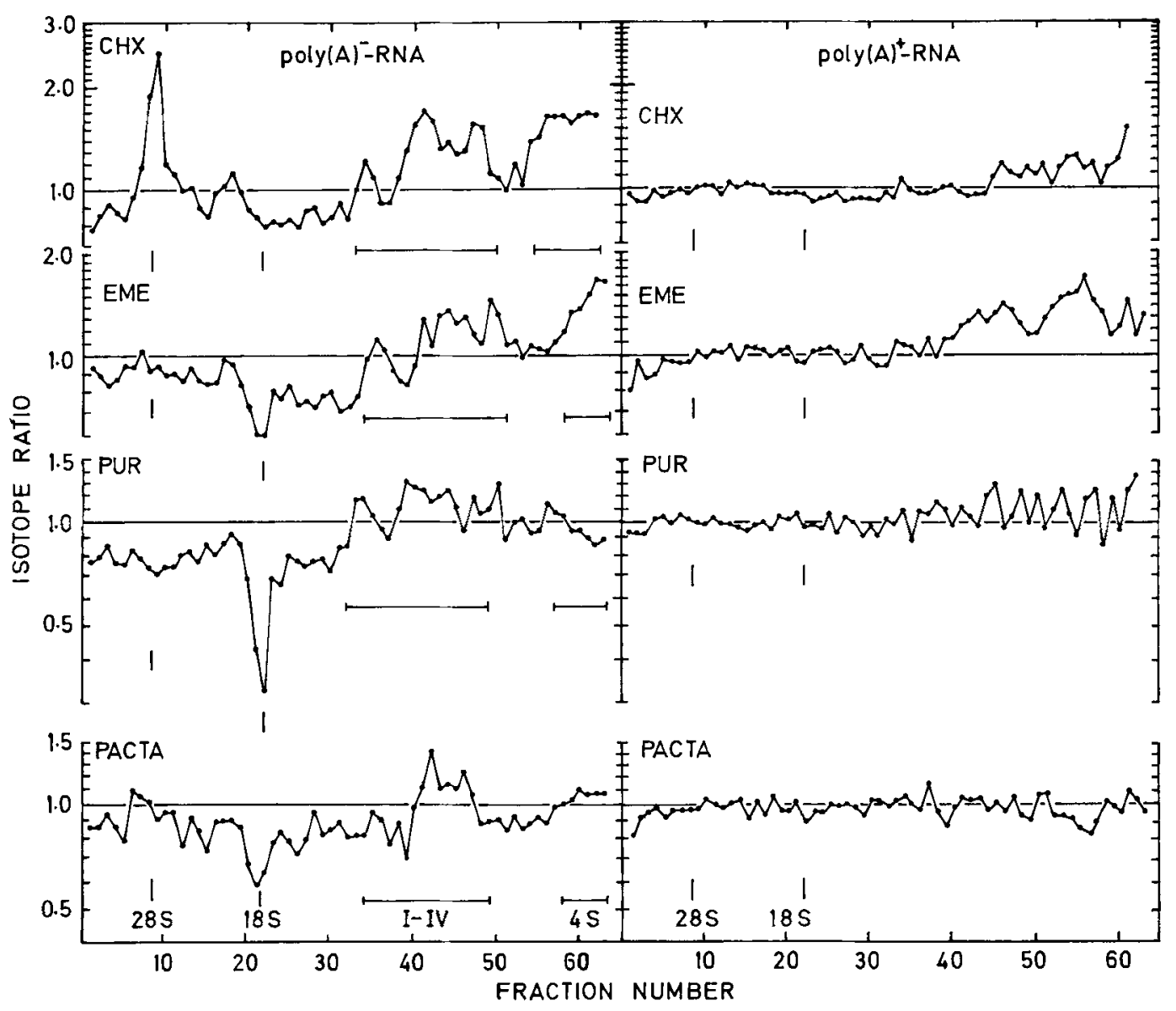

Figure 3. Effect of protein synthesis inhibitors on the cytoplasmic accumulation of newly synthesized RNA. Double labelled RNA was fractionated on poly(U)Sepharose and analyzed by polyacrylamide gel electrophoresis. The isotope ratios are given as $\mathrm{dpm}$ incorporated in the presence of inhibitor, divided by dpm incorporated in the absence of inhibitor, divided by the theoretical ratio. $\mathrm{CHX}$, cycloheximide $10^{-5} \mathrm{M}$; EME, emetin $2 \times 10^{-5} \mathrm{M}$; PUR, puromycin $5 \times 10^{-5} \mathrm{M}$; PACTA, pactamycin $2 \times 10^{-6} \mathrm{M}$.

are close to those reported for human histone mRNAs (1).

\subsection{The effect of protein synthesis inhibitors}

Since the effect of protein synthesis inhibitors on the cytoplasmic accumulation of RNA might not only be a result of an arrested production of protein as such, but could possibly depend on the mechanism of inhibition, four different inhibitors with different mechanism of action were chosen for study. Cycloheximide and emetin promote polysome stabilization, owing to their inhibition of elongation while pactamycin, as an inhibitor of initiation, causes a breakdown of polysomes. Puromycin, by acting as an acceptor of nascent peptides instead of aminoacyltRNA, may destabilize the association between the ribosomal subunits, thereby leading to a dissociation of the polysomes.

The dose dependent inhibition of protein synthesis was analyzed by labelling the cells with $\left[{ }^{14} \mathrm{C}\right]-$ leucin, (see 2.4), and the minimum inhibitor concentration causing about $95 \%$ inhibition within the first $15 \mathrm{~min}$ of action was then chosen for further study.

The effect of protein synthesis inhibition was analyzed in double labelled RNA appearing in 
Table I.

Effect of protein synthesis inhibition on the cytoplasmic accumulation of poly(A)--RNA during the first 45 min of treatment.

\begin{tabular}{lllll}
\hline Treatment & 28 S rRNA & 18 S rRNA & tRNA & histone mRNA \\
\hline Cycloheximide $10^{-5} \mathrm{M}$ & + & - & + & + \\
Emetin $2 \times 10^{-5} \mathrm{M}$ & 0 & - & + & + \\
Puromycin $5 \times 10^{-5} \mathrm{M}$ & - & - & 0 & + \\
Pactamycin $2 \times 10^{-6} \mathrm{M}$ & 0 & - & 0 & + \\
\hline
\end{tabular}

the cytoplasm during the first $45 \mathrm{~min}$ (see 2.3). First, the integrated mean ratio obtained after electrophoresis of the RNA was compared to the isotope ratio expected in case the incorporation had not been changed by the inhibitors. Since the uridine concentration was the same in both cultures, this theoretical ratio could

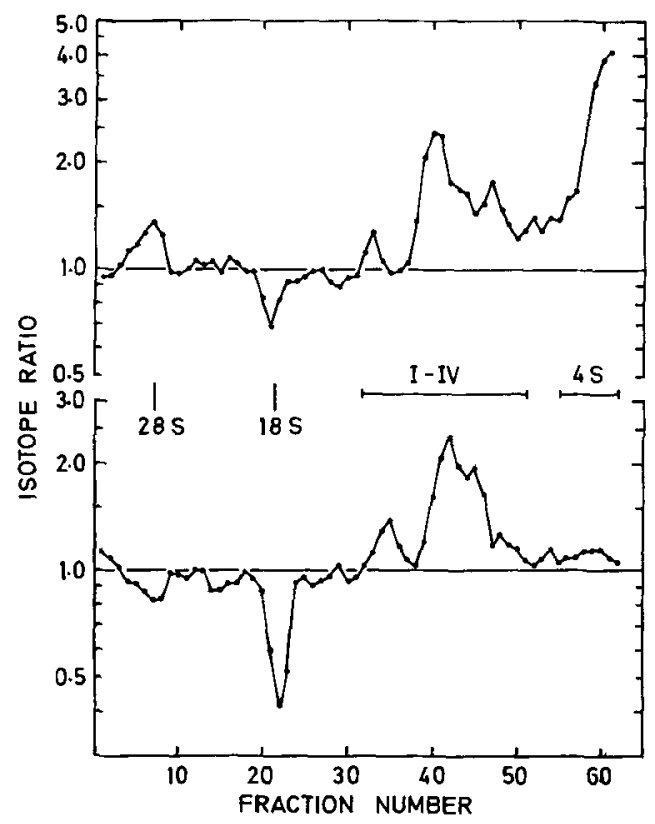

Figure 4. Effect of protein synthesis inhibition on the cytoplasmic accumulation of newly synthesized poly(A)-RNA in the presence of hydroxyurea. Cell cultures were incubated with $5 \mathrm{~mm}$-hydroxyurea, and cycloheximide $10^{-5} \mathrm{M}$ (upper curve) or puromycin $5 \times 10^{-5} \mathrm{M}$ (lower curve) was added after $10 \mathrm{~min}$. Double isotope analysis of RNA was performed as described under 2.3, followed by electrophoresis of poly(A)RNA. Isotope ratios are given as dpm plus inhibitor divided by dpm minus inhibitor, divided by the theoretical ratio. simply be calculated from the radioactive concentrations in the culture media. However, due to the self decomposition of $\left[{ }^{3} \mathrm{H}\right]$-uridine during storage, the isotope ratio was measured in uridine from the mixed media, obtained at the end of the incubation period, after separation by thin layer chromatography.

Irrespective of the inhibitor used, the isotope ratio of $\operatorname{poly}(\mathrm{A})^{+}-\mathrm{mRNA}$ was found to lie within $\pm 10 \%$ from the theoretical ratio, without any systematic deviations. Moreover, statistical analysis of the isotope ratios in single gel slices showed that less than $1 / 3$ deviated by more than $2 \mathrm{SD}$ from the integrated mean ratio. Since this is within the error of determination, inhibition of protein synthesis could not by this method be shown to have any effect on the cytoplasmic accumulation of polyadenylated RNA within the first $45 \mathrm{~min}$. The ratios are shown in Figure 3.

In contrast, a number of changes were induced in poly(A)--RNA, as shown by the isotope ratios in Figure 3. Statistical analysis showed these changes to be significant, since $80-85 \%$ of the ratios in single gel slices deviated by more than 2 SD from the integrated mean ratio. This was also the case when related to the theoretical ratio.

The more detailed changes in poly(A)--RNA are shown in Figure 3 and summarized in Table I. It is seen that all four inhibitors increased the labelling of histone mRNA by $20-80 \%$, and decreased the labelling of $18 \mathrm{~S}$ rRNA by $20-70 \%$. Accumulation of $28 \mathrm{~S}$ rRNA became $20-30 \%$ inhibited in the presence of puromycin, but was not significantly changed by emetin and pactamycin. However, a 50-150\% stimulation of the labelling in $28 \mathrm{~S}$ rRNA was observed after incubation with cycloheximide. Labelling of 
tRNA was increased by $50-60 \%$ in the presence of cycloheximide and emetin, but remained unaffected by puromycin and pactamycin.

As seen in Figure 3, labelling of other components of the non-polyadenylated RNA was also changed by protein synthesis inhibition, each inhibitor causing a characteristic change in the pattern of incorporation, most clearly observed in the upper part of the gels. In an attempt to obtain a more clear picture of the incorporation in other parts of the non-polyadenylated RNA, an experiment was performed in the presence of hydroxyurea, in order to possibly inhibit histone mRNA synthesis. However, as seen in Figure 4, the inhibitory action of hydroxyurea was overcome by cycloheximide and puromycin, so that the incorporation pattern was not qualitatively much changed.

It thus appears from these experiments that the cytoplasmic accumulation of a number of non-polyadenylated RNAs is tightly coupled to the synthesis of proteins. For some RNA species, like $28 \mathrm{~S}$ rRNA and tRNA, a demonstration of this coupling depends on the more detailed mechanism of protein synthesis inhibition.

\section{DISCUSSION}

The coordination of the process of transcription with that of translation is one of the fundamental regulatory control mechanisms of the cell. Since treatment of cells with protein synthesis inhibitors induces an integral response of high complexity, a detailed understanding of this coupling can only be obtained through analysis in a more purified system. However, this requires not only that the changes induced in RNA synthesis have been characterized on a more general level, but in particular, that the tightness of coupling, or stringency, is known, since a more stringent response would be expected to be more closely related to the initial effect of protein synthesis inhibition.

The accumulation of $\operatorname{poly}(A)^{+}-m R N A$ in the cytoplasm was found to be unaffected by all four protein synthesis inhibitors used, as indicated by comparison of the integrated mean ratio with the isotope ratio of uridine in the media (the theoretical ratio). Strictly speaking, changes in intracellular UTP specific activity and RNA synthesis rate could have outbalanced each other, but since none of the inhibitors induced a systematic deviation from the theoretical ratio, this possibility was not tested. (An increase in UTP specific activity previously observed after cycloheximide treatment (9) was not significant in repeated experiments.) Nor were any relative changes reproducibly observed when analyzing the deviations of the ratios in single gel slices from the integrated mean ratio. The significance of this result was tested by conversion of the amount of radioactivity represented by 2 SD of the isotope ratios to number of RNA molecules per cell. In a previous study it was found, that about 41,000 molecules of tRNA and 6,200 molecules of other RNA species accumulate in the cytoplasm during $45 \mathrm{~min}$ (9). From the distribution of radioactivity shown in Figure 1, poly $(\mathrm{A})^{+}-\mathrm{mRNA}$ was then found to represent 2,400 molecules per cell, and deviations of the isotope ratios corresponding to \pm $2 \mathrm{SD}$ could thus be calculated to represent between \pm 2 and \pm 20 molecules per cell. Since the average production rate per sequence is estimated to be about 1 copy/hour (9), it is concluded that considerable changes in the accumulation of polyadenylated mRNA could have escaped detection in the present experiment.

In contrast, the accumulation of non-polyadenylated RNA was differentially changed by protein synthesis inhibition. Thus, more than 80 $85 \%$ of the ratios of single gel slices deviated by more than 2 SD from the integrated mean ratio and the theoretical ratio. Four peaks of radioactivity were tentatively identified as being mRNA for histones by virtue of their lack of polyadenylation, their sensitivity to DNA synthesis inhibition with hydroxyurea as well as their apparent molecular weights. These properties are characteristic for histone mRNA from a variety of other organisms (13).

All four inhibitors increased the labelling of histone mRNA by $20-80 \%$ during the $45 \mathrm{~min}$ time interval. Since the delay between synthesis and cytoplasmic appearance of histone mRNA is extremely short (13), this effect may rather be due to an increased synthesis rate, than to an accelerated nuclear-cytoplasmic transfer of newly synthesized molecules. On the other 
hand, half-lives for histone mRNA have been estimated to $40 \mathrm{~min}$ in HeLa cells (11) and 3-5 hours in mouse $3 \mathrm{~T} 6$ fibroblasts (8), and it cannot be excluded that the effect observed in the present study might to some extent be due to a stabilization of this RNA as well. Thus, in HeLa cells an increased level of histone mRNA was found after 1-3 hours of cycloheximide treatment $(2,18)$.

The uncoupling of DNA and histone mRNA synthesis by cycloheximide and puromycin agrees well with earlier observations where cycloheximide was found to prevent a rapid breakdown otherwise induced by hydroxyurea (3). Since in the present study, hydroxyurea was added before protein synthesis inhibitors, it seems that cycloheximide and puromycin are able to reverse the effect of hydroxyurea. These results suggest that the rate of cytoplasmic accumulation is negatively controlled by proteins that may either be rather shortlived, or, exert their effect with a very short delay after being synthesized. The histones themselves might possibly exert this regulatory function.

The stimulatory effect of protein synthesis inhibition on the labelling of TRNA showed a correlation to the polysome stabilizing ability of cycloheximide and emetin, in contrast to puromycin and pactamycin, which had no effect. In view of the 41 hour half-life estimated for tRNA in rat thymocytes (9), as well as the very short delay between synthesis and migration to the cytoplasm, this effect is most probably explained as an increased production rate of tRNA. This observation confirms an earlier work, in which the effects of polysome stabilizing and destabilizing inhibitors were compared (22). The stimulatory effect of emetin but not of pactamycin adds to their list of inhibitors showing this correlation, and supports their hypothesis that $\mathrm{TRNA}$ synthesis may be regulated by a factor, whose effective concentration is determined by an equilibrium between a free and a polysome bound form. A stimulatory effect of puromycin on tRNA synthesis observed by WILLIS et al. (24) does not necessarily contradict this theory, since the premature chain termination induced by puromycin not always leads to a disaggregation of polysomes (10). The 50 to $60 \%$ stimulation of tRNA synthesis obser- ved in the present experiments is calculated to represent about 27,000 molecules per cell, or a stimulation of about $600 \mathrm{tRNA}$ molecules per min. Since eucaryotic cells contain in the order of 1,000 tRNA genes (14), this effect of protein synthesis inhibition may be exceedingly complex.

It is well documented that the synthesis of rRNA depends on a continuous supply of proteins. Synthesis of the $45 \mathrm{~S}$ ribosomal precursor has been shown to be unaffected by concentrations of cycloheximide which are not much higher than required for efficient inhibition of protein synthesis (19). In contrast, the formation of $41 \mathrm{~S}$ and $21 \mathrm{~S}$ pre-rRNA is rapidly blocked, resulting in a complete inhibition of the formation of $18 \mathrm{~S}$ rRNA, while $28 \mathrm{~S}$ rRNA may be produced at a reduced rate $(20,21,23)$.

The effect of emetin, puromycin and pactamycin seems to confirm this result, since the isotope ratio was much decreased in $18 \mathrm{~S} r \mathrm{RNA}$, and to a lesser extent, or not at all, in $28 \mathrm{~S}$ rRNA. However, the apparent difference in inhibition may be smaller than indicated by the isotope ratios. Owing to the fact that the nuclear pool of $18 \mathrm{~S}$ rRNA is extremely small, the labelled $18 \mathrm{~S}$ rRNA accumulating in the cytoplasm during 45 min would be expected to represent almost entirely the amount synthesized during that period. With $28 \mathrm{~S}$ rRNA this is not so, because the newly synthesized molecules are diluted in a sizable nuclear pool (5), so that the specific activity of radiolabelled 28 $\mathrm{S}$ rRNA in the cytoplasm after $45 \mathrm{~min}$ would be considerably lower than of $18 \mathrm{~S}$ rRNA. Even if both RNA species had been inhibited to the same extent, the isotope ratio would have been decreased less for $28 \mathrm{~S}$ rRNA than for $18 \mathrm{~S}$ rRNA, owing to a relatively higher background level of radioactivity (see Figure 1).

The stimulatory effect of cycloheximide on the labelling of $28 \mathrm{~S}$ rRNA was unexpected. It might possibly be explained by an accelerated nuclear-cytoplasmic transfer of preribosomal particles, since, for the reasons mentioned above, this would be expected to increase the labelling of cytoplasmic $28 \mathrm{~S}$ rRNA, but hardly affect the radioactivity of $18 \mathrm{~S}$ rRNA in the cytoplasm after the 45 min time interval.

Since this effect was only observed with cyclo- 
heximide, it did not seem to be due to shortage of proteins, unless the residual proteins synthesized in the presence of cycloheximide differed in some way from those produced in the presence of the other inhibitors. Alternatively, cycloheximide might possibly exert its action not by virtue of its effect on protein synthesis, but in another way decrease the affinity of pre-ribosomal particles to the nuclear compartment.

In summary, the present experiments show, that by inhibition of protein synthesis, two types of stringent responses are induced. One is elicited by protein synthesis inhibition in itself ( 18 $\mathrm{S}$ rRNA, histone mRNA), whereas the other is inhibitor specific, and related to the mechanism of inhibition, or to other unknown properties of the inhibitors (tRNA, $28 \mathrm{~S}$ rRNA).

\section{ACKNOWLEDGEMENTS}

I wish to thank HANNE S. HEGELUND for her skilled technical assistance. Thanks are also due to Dr. J.E. GRaDY, The Upjohn Company, Michigan, USA for donating the sample of pactamycin used in this study.

This paper is dedicated to Professor HeInz HOLTER on occasion of his 80th birthday, in memory of the happy time I spent as a student at the Physiological Department of the Carlsberg Laboratory from 1969 to 1971.

\section{REFERENCES}

1. Borun, T.W. K. Ajiro. A. Zweidler. T.W DOLBY \& R.E. STEPHENS: Studies of human histone messenger RNA, II. J. Biol. Chem. 252, 173-180 (1977)

2. BREINDL. M. \& D. Gallwitz; Effects of cordycepin, hydroxyurea and cycloheximide on histone mRNA synthesis in syncronized HeLa cells. Mol. Biol. Rep. 1, 263-268 (1974)

3. Butler, W.B. \& G. Mueller: Control of histone synthesis in HeLa cells. Biochim. Biophys. Acta 294, 481-496 (1973)

4. Chen, C.-L.C. \& P. Feigelson: Cycloheximide inhibition of hormonal induction of $\alpha_{24}$-globulin mRNA. Proc. Natl. Acad. Sci. USA 76, 2669-2673 (1979)

5. CoOper. H.L.: Degradation of $28 \mathrm{~S}$ RNA late in ribosomal RNA maturation in non-growing lymphocytes and its reversal after growth stimulation. J. Cell Biol. 59, 250-254 (1973)
6. Cross, F.R \& J.E. DARnell, JR.: Cycloheximide stimulates early adenovirus transcription if early gene expression is allowed before treament. $\mathrm{J}$. Virol. 45, 683-692 (1983)

7. DeLAP. L.\& P. FEIGElson: Effect of cycloheximide on the induction of tryptophan oxygenase mRNA by hydrocortisone in vivo. Biochem. Biophys. Res. Commun. 82, 142-149 (1978)

8. Delisle. A.J., R.A. Graves, W.F. Marzluff \& L.F. JOHNSON: Regulation of histone mRNA production and stability in serum-stimulated mouse 3T6 Fibroblasts. Mol. Cell. Biol. 3, 19201929 (1983)

9. ENGELHARDT. M.: Quantitative analysis of mRNA synthesis during early cortisol action on rat thymocytes: Restricted size of a possible hormone response. Mol. Cell Endocrinol. 29, 309-333 (1983)

10. ERnEST, M.J: Regulation of tyrosine aminotransferase messenger ribonucleic acid in rat liver. Effect of cycloheximide on messenger ribonucleic acid turnover. Biochem. 21, 6761-6767 (1982)

11. HeinTZ, N. H.L. Sive \& R.G. Roeder: Regulation of human histone gene expression: Kinetics of accumulation and changes in the rate of synthesis and in half-lives of individual histone mRNAs during the HeLa cell cycle. Mol. Cell Biol. 3, 539-550 (1983)

12. IYNEDJIAN, P.B. \& M.M. JACOT: Glucocorticoid dependent induction of mRNA coding for phosphoenolpyruvate carboxykinase (GTP) in rat kidney. Eur. J. Biochem. 111, 89-98 (1980)

13. KEDES. L.H: Histone messengers and histone genes. Cell 8, 321-331 (1976)

14. KUBLI, E.: The structure and function of tRNA genes of higher eucaryotes. Experientia 37, 1-9 (1981)

15. LOENING, U: The fractionation of high-molecular weight ribonucleic acid by polyacrylamide-gel electrophoresis. Biochem. J. 102, 251-257 (1967)

16. MCKNIGHT, G.S.: The induction of ovalbumin and conalbumin mRNA by estrogen and progesterone in chick oviduct explant cultures. Cell 14, 403-413 (1978)

17. Phillips, W.F. \& E.H. McConkey: Relative stoiciometry of ribosomal proteins in HeLa cell nucleoli. J. Biol. Chem. 251, 2876-2881 (1976)

18. Stimac, E., V.E. Groppi \& P. Coffino: Increased histone mRNA levels during inhibition of protein synthesis. Biochem. Biophys. Res. Commun. 114, 131-137 (1983)

19. Stoyanova, B.B. \& M.D. Dabeva: Ribosomal RNA precursor transcription in rat is not dependent on continuous synthesis of proteins. Biochim. Biophys. Acta 608, 358-367 (1980) 
20. Stoyanova, B.B. \& A.A. Hadjiolov: Alterations in the processing of rat liver ribosomal RNA caused by cycloheximide inhibition of protein synthesis. Eur. J. Biochem. 96, 349-356 (1979)

21. Warner, J.R., M. Girard, H. Latham \& J.-E. DARNELL: Ribosome formation in HeLa cells in the absence of protein synthesis. J. Mol. Biol. 19, 373-382 (1966)

22. Westerberg, U.-B., G. Bolcsfoldi \& E. ELIASSON: Control of transfer RNA synthesis in the presence of inhibitors of protein synthesis. Biochim. Biophys. Acta 447, 203-213 (1976)
23. Willems, M., M. Penman \& S. Penman: The regulation of RNA synthesis and processing in the nucleoli during inhibition of protein synthesis. $J$. Cell Biol. 41, 177-187 (1969)

24. Willis, M., J.B. BASEMAN \& H. AmOS: Noncoordinate control of RNA synthesis in eucaryotic cells. Cell 3, 179-184 (1974)

25. WOOL, I.G. \& G. STOFFLER: Determination of the size of the pool of free ribosomal proteins in rat liver cytoplasm. J. Mol. Biol. 108, 201-218 (1976) 